\title{
ИМЕНА. ПОРТРЕТЫ
}

\section{9 - ГОД ТЕАТРА В РОССИИ}

УДК 7.034.8(4Фра)"17"(092)Фрагонар Ж.-О.

ББК 85.143-022.12(4Фра)51-8 Фрагонар Ж.-О.,44

DOI 10.25281/2072-3156-2019-16-4-406-417

\section{Е.Е. АГРАТИНА}

\section{TВОРЧЕСТВО ЖАНА-ОНОРЕ ФРАГОНАРА И ТЕАТРАЛЬНАЯ КУЛЬТУРА ХVIII ВЕКА}

\section{Елена Евгеньевна Агратина,}

Московская государственная академия

хореографрии,

кафедра хореографии и балетоведения,

доцент

2-я Фрунзенская ул., д. 5, Москва, 119146, Россия

кандидат искусствоведения, доцент

ORCID 0000-0001-9842-0967; SPIN 6691-3631

E-mail: agratina_elena@mail.ru

Реферат. $B$ статье впервые рассматривается творчество мастера XVIII в. Жана-Оноре Фрагонара (1732-1806) в контексте театральной культуры того времени. Будучи учеником Франсуа Буше (1703-1770), долгое время работавщего в качестве театрального декоратора, Фрагонар с юности имел возможность приобщиться к миру театра. Увлечение живописиа сиеной значительно повлияло на тематический и образный состав его произведений. Ранние исторические полотна Фрагонара, такие как
«Иеровоам, приносящийжертву идолам» (1752, Школа изящных искусств, Париж), созданы под воздействием барочного театрально-декорационного искусства и непосредственно оперных постановок. Несомненно, более близкому знакомству Фрагонара с театром способствовало длительное пребывание в Италии, где работали в то время знаменитые семейства театральных декораторов Бибиена и Галлиари. Особое внимание в статье уделено замыслу и исполнению картины «Жреи, Корез жертвует собой во имя спасения Каллирои» (1765, Лувр), выполненной не без оглядки на оперу «Каллироя», популярную в Париже XVIII века. Театр вдохновил мастера и на создание знаменитой костюмированной серии «Фантазийных портретов», один из которых изображает Мари-Мадлен Гимар (1743-1816), не только позировавшую художнику, но и заказавшую ему оформление собственного особняка, задуманного как храм музы таниза Терпсихоры. Также Фрагонар стал автором нескольких панорамных жанровых полотен, передающих атмосферу столь попу- 
лярного тогда уличного театра. На примере творчества этого яркого мастера становится очевидной взаимосвязь искусств, определившая характер культурной среды той эпохи и требующая неизменного внимания со стороны современных исследователей.

Ключевые слова: искусство XVIII века, рококо, живопись, театр, театральное искусство. Для цитирования: Агратина Е.Е. Творчество Жана-Оноре Фрагонара и театральная культуpa XVIII века// Обсерватория культуры. 2019. T. 16, № 4. C. 406-417. DOI: $10.25281 / 2072-$ 3156-2019-16-4-406-417.

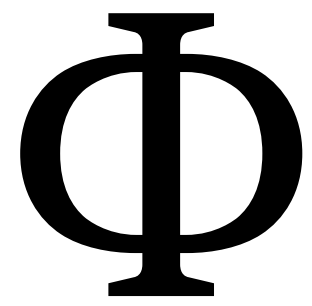

ранцузские художники эпохи рококо имели естественную и неоспоримую предрасположенность к театру. Этому можно найти множество объяснений, одинаково убедительных и справедливых. Во-первых, театр во Франции этого времени переживал расцвет, пусть и не столь пышный, как в предшествующее столетие. Известно, что в середине XVIII в. в Париже действовало двадцать семь театров [1, p. 55] (здесь и далее перевод наш. - E. А.). Среди них наибольшим влиянием пользовались Театр Пале-Рояль, Комеди Франсез и Театр итальянской комедии. Постановки, отличающиеся продолжительностью, торжественностью и роскошным оформлением, привлекали публику самого разного социального положения и активно обсуждались в прессе. Художник был фигурой, совершенно необходимой для создания спектакля, а потому видных мастеров постоянно пытались подключить к изготовлению театральных декораций. Итальянские сценографы, в частности представители семейства Бибиена, задали чрезвычайно высокую планку в этой области, и удовлетвориться работой ремесленников и второразрядных живописцев было уже невозможно, даже когда речь шла не о придворных постановках. Если художник и не оказывался в театре в качестве оформителя, он обязательно бывал там в качестве зрителя, причем постоянно - театр составлял столь значительную часть культуры того времени, что не приобщиться к его миру было совершенно немыслимо. Из театра художник выносил массу впечатлений, которые имел возможность отразить в своем творчестве. Учитывая, что на вершине иерархии, утвержденной Королевской академией живописи и скульптуры, находился в то время исторический жанр, обращение мастеров кисти к театру оказывалось особенно актуальным. Театр и историческая живопись эксплуатировали зачастую одни и те же сюжеты, использовали один и тот же, всем тогда понятный язык жестов.

Разумеется, увлечение театром могло проявить себя и в творчестве мастеров портретного и бытового жанров. Создатели галантных сцен постоянно оглядывались на театральные подмостки, выводя в своих композициях любимых героев. Таков пример Антуана Ватто (16841721), на полотнах которого действуют персонажи комедии дель арте, весьма популярной во Франции XVIII века. Любимый заказчиками костюмированный портрет также был во многом вдохновлен сценой, ибо где еще можно было увидеть преображение очаровательной дамы в Гебу или Венеру.

Представители театрального сообщества нередко выступали и в роли заказчиков, приглашая живописцев для создания портретов или украшения особняков и укрепляя, таким образом, связи между театральной и художественной средой. Как считает Г. Кан, играл свою роль и тот факт, что художники и артисты имели одних и тех же покровителей, которые способствовали обмену заказами между ними [2, p. 16].

Героем нашего очерка является мастер, имя которого не нуждается в представлении, Жан-Оноре Фрагонар (1732-1806). Уроженец Грасса, он оказался в Париже в ранней юности. Получив начальные знания в мастерской Ж.-Б.-С. Шардена (1699-1779), Фрагонар перешел от него к $Ф$. Буше (1703-1770), самому популярному тогда мастеру, любимцу маркизы де Помпадур, плодовитому и деятельному художнику, занимавшемуся всем: от росписи вееров до создания плафонов. Надо думать, что именно во времена ученичества у Буше Фрагонар впервые знакомится с театром и даже получает некоторое представление о том, в чем состоит работа театрального декоратора. 


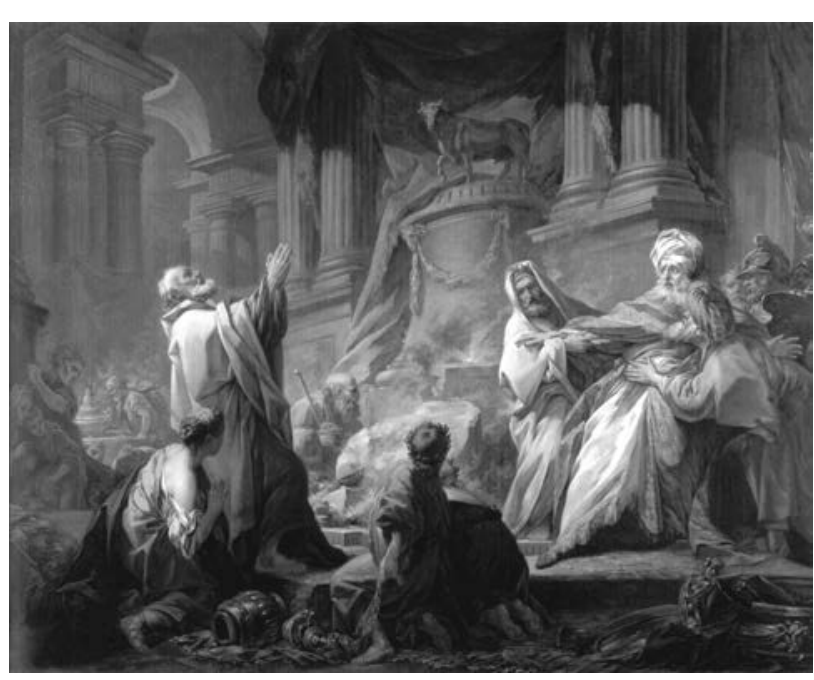

Рис. 1. Ж.-0. Фрагонар. Иеровоам, приносящий жертву идолам. 1752. Масло, холст. $145 \times 115$. Школа изящных искусств, Париж

Дело в том, что, являясь истинным сыном XVIII века, Буше пробовал силы и в области сценографии. Эта сторона творчества мастера малоизвестна и редко попадает в поле зрения исследователей, в чем повинна плохая сохранность произведений. Тем не менее театр занимал значительное место в жизни Буше. С 1730-х гг. художник трудился для Парижской оперы, а в 1760-1766 гг. официально занимал должность ее директора.

Французский исследователь М. Фенай отмечает: «Среди всех прочих работ Буше находил время писать театральные декорации, которыми он регулярно занимался с 1737 года. От этих декораций осталось несколько рисунков к "Деревушке Иссы”, “Сильвии”, “Ринальдо и Армиде”, “Кастору и Поллуксу”, но ни одна из этих масштабных декораций не дошла до наших дней. Мы можем судить о них лишь по свидетельствам современников и по гобеленам, которые дают представление о том, на что Буше был способен в области театра» [3, p. 53]. Упомянутые гобелены, созданные в 1751-1757 гг., в самом деле перекликаются с названными постановками. Серия носит наименование «Фрагменты оперы» и включает в себя четыре произведения: «Уснувший Ринальдо», «Вертумн и Помона», «Сон Иссе» и «Венера с амурами». Разумеется, гобелены не могли являть собой точного повторения декора определенных постановок, однако очевидно, что они были вдохновлены театрально-декорационным искусством.

Также в Салоне 1742 г. Буше выставил картину «Деревушка Иссы» (Музей Пикардии, Амьен). Эта композиция должна была быть повторена в качестве декорации для оперы [3, p. 91], а потому строится по законам сценической декорации ${ }^{1}$. Роль кулис исполняют стоящие справа и слева живописные деревенские домики. «Задник» занят изображением пейзажа, в центре возвышается раскидистое дерево, под которым устроен навес, стоит стол, стул и скамья.

Театральные впечатления и некоторые знания в области сценографии, полученные в ателье Буше, были важны для юного Фрагонара. Чрезвычайно одаренный, способный успешно работать практически в любом жанре, он изначально мечтал о карьере исторического живописца. Очевидно, к этому подталкивал его и учитель. Как человек, не имеющий официального статуса в Академии, Фрагонар не мог участвовать в конкурсе на Римскую премию. Это была очень престижная награда. Удостоившиеся ее мастера получали стипендию и возможность несколько лет продолжать обучение в Италии, где их принимала Французская академия в Риме. Это учреждение было своеобразным итальянским филиалом Королевской академии живописи и скульптуры и одновременно являлось высшей ступенью академического образования. Изначально Фрагонар и не помышлял об участии в конкурсе, который полагал для себя недоступным. Тем не менее Буше использовал свой весомый авторитет, чтобы Фрагонара допустили к участию как его ученика. На конкурс молодой художник представил свою первую историческую картину «Иеровоам, приносящий жертву идолам» $(1752$, Школа изящных искусств, Париж) (рис. 1). Неожиданно полотно удостоилось первой премии.

Предложенный Академией сюжет полотна был заимствован из Ветхого Завета. Иеровоам - старый слуга Соломона, избранный царем над половиной разделенного после смер-

1 Опера «Исса» на слова А.-У. Деламотта и музыку А.-К. Детуша впервые была поставлена в Фонтенбло в 1697 году. Спектакль был повторен в 1708 и 1749 годах. Последняя постановка шла в декорациях Буше. 
ти Соломона Израиля, стремился удержать народ подальше от Иерусалима, дабы не пробудить в нем желание вновь воссоединиться с Иудеей. Также Иеровоам решил, что религиозный культ, где боги представали бы в виде зримых изображений, окажется ближе людям, чем культ незримого и вездесущего Бога. Поэтому Иеровоам основал два новых святилища: одно в Вефиле, другое в Дане и установил там изображения золотых тельцов. Во время освящения жертвенника в Вефиле, в тот момент, когда Иеровоам совершал воскурения фимиама, в храм явился Пророк, который «произнес к жертвеннику слово Господне, и сказал: жертвенник, жертвенник! так говорит Господь: вот, родится сын дому Давидову, имя ему Иосия, и принесет на тебе в жертву священников высот, совершающих на тебе курение, и человеческие кости сожжет на тебе <...>. И дал в этот день знамение, сказав: вот знамение того, что это изрек Господь: вот, этот жертвенник распадется, и пепел, который на нем, рассыплется $<. .>$ жертвенник распался, и пепел с жертвенника рассыпался, по знамению, которое дал человек Божий словом Господним» (3 Цар. 13:2, $3,5)$. Иеровоам велел схватить пророка и простер над ним руку, которая немедленно онемела. Испуганный царь стал просить пророка вступиться за него перед Богом. «И умилостивил человек Божий лице Господа, и рука царя поворотилась к нему, и стала как прежде» (3 Цар. 13:4, 6). Иеровоам, однако, не вернулся на праведный путь, до конца жизни оставшись язычником.

Фрагонар решил совместить на своем полотне два самых драматичных момента этой библейской истории: момент падения жертвенника и наказания Иеровоама. Сразу обращает на себя внимание величественная архитектура храма, в котором разворачивается действие. Интерьер, представленный в угловом ракурсе, кажется лабиринтом из арок, сводов и целого леса канеллированных колонн. Несомненно, эта архитектура имеет отсылку к театрально-декорационному искусству того времени, где господствует итальянский барочный вкус. Изобретенная представителями клана театральных декораторов Бибиена «угловая перспектива» (veduta per angolo) позволила в значительной степени усложнить иллюзор- ную архитектуру, превратить ее к «какую-то странную каменную утопию, <...> где громоздятся одни только прекрасные, тонкие, ненужные и чистые формы, где без устали гуляешь по прохладным и огромным, полным воздуха и света галереям и террасам» [4, с. 40]. Во Франции середины XVIII в. итальянские театральные декораторы уже успели побывать, к тому же их произведения могли быть известны Фрагонару по гравюрам и зарисовкам.

Основное действие происходит в центре композиции, где возвышается жертвенник с изваянием золотого тельца. По слову Пророка камень жертвенника рушится, а в воздух поднимаются клубы пепла. Иеровоам, поднявший руку на Пророка и пораженный господней карой, в ужасе отшатывается. Его подхватывают два бородатых жреца. Пророк со сложенными руками молит Бога о прощении Иеровоама. Остальные свидетели происшествия - мужчины и женщины, одна из которых с ребенком, застыли в позах, выражающих изумление и благоговение. Работая над фигурами, Фрагонар применяет любопытный прием, который также дает определенную отсылку к театру: фигуры на первом плане почти полностью погружены в тень и даны чуть ли не контражуром. Свет выхватывает лишь их плечи и головы. Зато центральная часть композиции, где происходят главные события, прекрасно освещена, причем акцент сделан на двух основных фигурах: Иеровоама и Пророка. Даже современный зритель способен ощутить драматичность представленного момента и проникнуться духом хорошо срежиссированной сцены.

Для Фрагонара победа в конкурсе на Римскую премию стала большим триумфом, который, однако, не вскружил голову молодому художнику. Он прекрасно представлял себе, сколько всего ему еще предстоит изучить, чтобы из подающего большие надежды новичка превратиться в зрелого мастера. Поездке в Италию предшествовало длительное обучение в Школе покровительствуемых художников ${ }^{2}$.

${ }^{2}$ Школа покровительствуемых художников (Ecole royale des élèves protégés). Организованная по приказу короля Людовика XV школа открылась в 1748 г., всего за пять лет до поступления в нее Фрагонара. Первым директором был назначен Ш.-А. Куапель (1694-1752). Надзирать за работами молодых людей был поставлен 


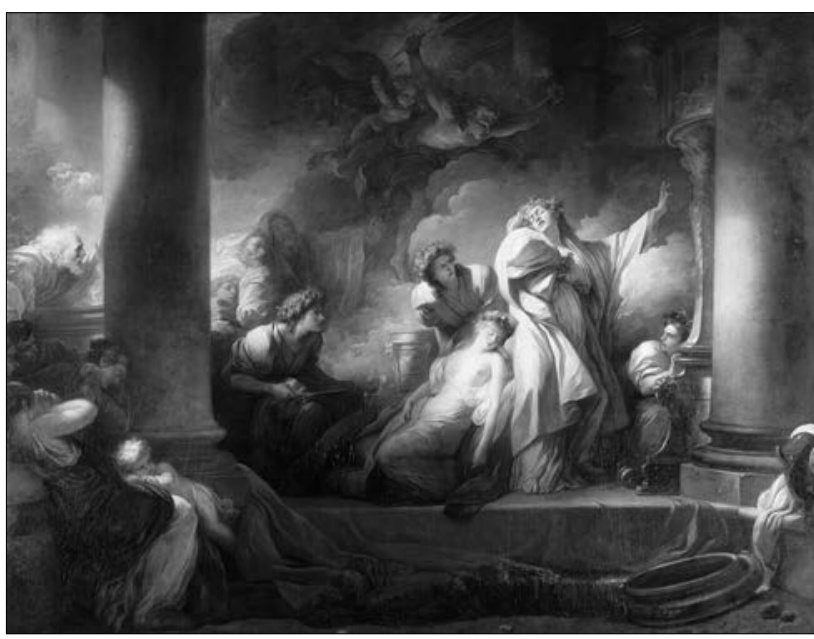

Рис. 2. Ж.-0. Фрагонар. Жрец Корез жертвует собой во имя спасения Каллирои.

1765. Масло, холст. $400 \times 309$. Лувр, Париж

С 1756 по 1762 г. Фрагонар провел в Италии. Следует сказать, что это пребывание, несомненно, было очень плодотворным и полезным для молодого мастера. Он посетил не только Рим и его окрестности, но также и другие города и важные исторические места: Неаполь, Помпеи и Геркуланум, Сиену, Флоренцию, Пизу, Венецию, Падую, Виченцу, Верону, Мантую, Реджо, Модену, Болонью, Парму и Колорно, Пьяченцу, Геную и Сан-Ремо [6, p. 118-119]. Вопрос знакомства Фрагонара с итальянским театром до сих пор остается совершенно неисследованным. Тем не менее не состояться это знакомство не могло. Италия - родина барочной оперы, подарившая миру целую плеяду театральных декораторов, рассеявшихся по всей Европе. Наиболее значительным, естественно, следует считать семейство Бибиена, происходившее из Болоньи ${ }^{3}$. Определенной известностью пользовалась

Ж. Дюмон (1701-1781), которого очень быстро сменил К. Ванлоо (1705-1765). Школа была создана только для лауреатов Римской премии, чтобы они с пользой провели время до отправления в Италию - ожидать свободных мест приходилось по несколько лет. Помимо возможности далеко продвинуться в мастерстве, ученики получали кров, питание, дрова и годовую стипендию в триста ливров. Для школы было отведено здание рядом с Лувром между площадью Старого Лувра и улицей Фроманто [5].

3 Родоначальником семьи был Джованни Мария Старший (1618-1665). В театре начали работать его сыновья Фердинандо (1657-1743) и Франческо (16591739). Наследовало им три следующих поколения, и династия Галлиари ${ }^{4}$. Трудно представить себе, что, прожив в Италии шесть лет и посетив такое количество городов, Фрагонар не бывал в театрах и не интересовался трудами театральных декораторов. П. де Ноляк свидетельствует, что Фрагонар, во всяком случае, зарисовывал руины античных театров [7, p. 69]. Документы, к сожалению, не зафиксировали эти посещения, однако последующие произведения Фрагонара показали, что театр по-прежнему занимает не последнее место в культурном окружении мастера. Любопытно, что привезенные Фрагонаром из Италии рисунки с изображениями итальянской природы и архитектурных памятников впоследствии стали использовать такие сценографы, как П.-А. Пари для изготовления театральных декораций, которые получили название «фрагонардесок» [8, p. 172].

По возвращении в Париж Фрагонар начал длительную работу над полотном, чтобы получить звание назначенного. Речь идет о картине «Жрец Корез жертвует собой во имя спасения Каллирои» (1765, Лувр) - произведении, которое не только обеспечило молодому художнику искомое звание, но и заслужило многие благосклонные отзывы современников (рис. 2). Сюжет был позаимствован из произведения Павсания (II в. н. э.), который описывает историю любви жреца бога Диониса Кореза к девушке Каллирое. Не добившись взаимности, жрец Корез обратился за помощью к божеству, которому служил. В отмщение за сердечные муки Кореза Дионис наслал на жителей всего города безумие. Бедствие должно было прекратиться, только если Каллироя, либо кто-то другой, согласившийся занять ее место, будет принесен в жертву. Корез, однако, не смог нанести смертельного удара

среди представителей которых необходимо отметить Алессандро (1686-1748), Джованни Марию Младшего (1693-1777), Джузеппе (1695-1757), Антонио (16971774), Джованни Карло Сичинио (1717-1760), Карло Бернардо (1721-1787), Фердинандо Антонио (17271788) и Филиппо (1765-1842). Как можно понять, взглянув на даты жизни, во время пребывания Фрагонара в Италии трое представителей знаменитого семейства были в состоянии творческой активности. Кроме того, в различных итальянских городах трудилось множество учеников Бибиена.

${ }^{4}$ Джованни Галлиари (1672-1722) и его сыновья Бернардино (1707-1794) и Фабрицио (1709-1790). 
своей возлюбленной и предпочел пожертвовать собственной жизнью. Этот сюжет Фрагонар воплотил с торжественностью и размахом театральной постановки. Действие происходит в храме, под сенью мощных и тяжелых колонн. Смысловой центр композиции немного сдвинут вправо и выделен светом. Здесь, на возвышении, застеленном алым покровом с золотой бахромой, разворачивается драма. Юная Каллироя в венке из роз, с обнаженной для удара грудью без чувств опускается на руки молодого жреца. Рядом Корез, облаченный в длинные жреческие одежды, вонзает себе в сердце кинжал. Второй рукой он будто бы пытается нащупать опору, однако встречает лишь бесплотный дым, исходящий от благовонных курильниц. Лицо Кореза, бледное, молодое, лишенное растительности, запрокинуто, глаза закрыты. На эту величественную и трагическую фигуру обращены взоры всех присутствующих. Три молодых прислужника с венками из листьев в пышных волосах смотрят на него с тревогой и испугом. Молодая женщина на первом плане закрывает лицо краем одежды, к ее коленям прижимается ребенок. Старые бородатые жрецы на заднем плане демонстрируют великий страх и изумление. Не сразу можно заметить погруженную в тень зловещую фигуру гения мести, парящую над головой Кореза. Колорит полотна построен на сочетании красного, белого, зеленого и золотистого цветов, однако не становится при этом слишком теплым, так как это снизило бы градус драматизма.

Законченная картина была выставлена в Салоне 1765 г. и вызвала благосклонные отклики со стороны большинства критиков. В первую очередь следует вспомнить Д. Дидро (1713-1784). Философ посвящает картине довольно длинное эссе в форме диалога со своим издателем Ф.-М. Гриммом (1723-1807). Дидро излагает якобы приснившийся ему сон, похожий на описание театральной постановки и совпадающий со сценой, представленной Фрагонаром. Указав в ходе увлекательной беседы на несколько недостатков, таких как невыразительность главной героини, написанной слишком блеклыми красками, собеседники делают вполне благоприятный для художника вывод: «Фрагонар написал прекрасную карти- ну. В ней - всё чародейство, все тонкие ухищрения, на какие способна палитра. Замыслы этого художника как нельзя более величественны; ему не хватает лишь правдоподобия красок и технического совершенства, которые со временем у него появятся, когда он наберется опыта» $[9$, с. 182].

Картина Фрагонара была представлена в Салоне под номером 176. В официальной брошюре, посвященной Салону, отмечалось, что это произведение принадлежит королю и с него будут сделаны воспроизведения на мануфактуре гобеленов [10, p. 30]. Притом, что Салон 1765 г. всегда упоминается исследователями как наименее богатый на критические сочинения и отзывы, Ш.-Ж. Матон де Лакур (1738-1793) оставил несколько писем, достаточно подробно характеризующих каждого из экспонентов. О Фрагонаре он пишет следующее: «Господин Фрагонар представил большую картину, которая предназначена к воспроизведению на мануфактуре гобеленов. Она изображает великого жреца Кореза, который жертвует собой для спасения Каллирои. Освещение передано весьма удачно. Головы хорошо подобраны. В той, что принадлежит Корезу, прекрасно сочетаются гордость и воодушевление. Кажется, зрители удивлены. Это произведение делает много чести своему создателю и является одним из самых прекрасных в Салоне» [11, р. 21]. Судя по этому отзыву, произведение имело полный успех. Фрагонар, чье имя было практически неизвестно французской публике, оказался в центре всеобщего внимания.

Возникает вопрос, почему полотно молодого мастера вызвало такой бурный отклик со стороны публики и критики? Как удавалось зрителям разобраться в перипетиях сюжета? Ответ следует искать также в области театра. На тот момент существовала и была хорошо известна публике опера «Каллироя» на музыку А.-К. Детуша $(1672-1749)$ и либретто П.-Ш. Руа (1683-1764), впервые поставленная в Париже в 1712 г. и впоследствии многократно повторенная. В пятом действии герои оказываются в храме жестокого божества. Перед глазами зрителей должна была разыграться та самая сцена, которая представлена на полотне Фрагонара. Либретто сообщает, 
что в первой сцене пятого акта «Театр представляет храм Бахуса, украшенный для жертвоприношения» [12, р. 57].

На сцене между героями должен был произойти следующий диалог:

Каллироя: Я дрожу. Заканчивай, пора.

Корез: Остановитесь. Я сам выбираю жертву.

Закалывает себя.

Каллироя: Вы умираете [12, p. 62].

Перед смертью Корез произносит (поет) еще один монолог и протягивает руку возлюбленной. Таким образом, то, что теперь нам кажется малоизвестным и запутанным, было хорошо знакомо французскому зрителю, а потому его интерес к полотну Фрагонара представляется вполне закономерным, также как и внимание со стороны критики.

Хотя вышеописанное полотно явилось последним историческим произведением Фрагонара, отношения художника с театром и представителями театрального мира на этом не окончились. Одним из самых значимых циклов произведений в творчестве Фрагонара являются так называемые «Фантазийные фигуры» (Les figures de fantaisie). Строго говоря, речь идет о серии портретов вполне реальных людей, однако очевидная костюмированность, театрализованность этих портретных изображений вкупе с необычной свободой исполнения заставили воспринимать эти произведения как некие «фантазии». П. Кюзен проводит прямую параллель между миром театра и этими изображениями, называя их «масками» и «актерами», хотя модели многих из них известны [13, S. 123]. В серию входят пятнадцать произведений, имеющих одинаковый размер и сходную композицию: показанные примерно до пояса фигуры отделены от зрителя каменным парапетом. Облаченные в пышные одежды они, как правило, не смотрят на зрителя и погружены в размышления или заняты какой-либо творческой деятельностью. Один из женских портретов серии традиционно считается изображением танцовщицы Мари-Мадлен Гимар (1743-1816) (Лувр). Изящная женская фигурка опирается на каменный парапет. Под руками у нее лежат письма и рисунки, рядом - раскрытый медальон.
Облегающее платье переливается от красного к зеленому. Пышный белый воротник обрамляет тонкую длинную шею, собранные на макушке волосы украшены лентами и перьями. Видимо, поскольку перед нами именно танцовщица, Фрагонар отходит от обычного поясного среза и показывает фигуру до уровня бедер. Это позволяет продемонстрировать ее изящество и изысканность почти танцевального движения.

На полотне Фрагонара Гимар еще совсем молода - ей около двадцати пяти лет. Заметим, что это была одна из самых успешных танцовщиц своего времени, сделавшая блистательную карьеру. Искусство балета активно развивалось в эту эпоху. Среди современных Фрагонару имен можно также назвать Мари-Анн Камарго (1710-1770), Гаэтано Вестриса (1729-1808), Жана-Жоржа Новерра (1727-1810). Мир танцовщиков и актеров вдохновлял мастеров кисти разнообразием движений и костюмов, которое они переносили и в портреты людей, не связанных со сценой, но желающих предстать в той или иной «роли».

Отношения Гимар с Фрагонаром имеют долгую историю. Известно, что в 1770-1773 гг. Гимар была занята обустройством дворца, подаренного ей Шарлем де Роганом, принцем де Субиз и построенного по проекту еще молодого тогда архитектора К.-Н. Леду (1736-1806).

Как раз в это время Фрагонар пробовал свои силы в области архитектурной декорации и имел немалый успех. Как пишут братья Гонкур, «этот волшебник, который так быстро творил из солнечных лучей, света и сияния, был создан для того, чтобы расписывать стены, которые тот век не хотел оставить в их нетронутой белизне, чтобы творить ложные небеса плафонов, под которыми финансисты и куртизанки того времени спасались от серого парижского неба. Фрагонар скоро стал модным декоратором, которого искали, звали и благословляли в застраивающемся Шоссе д’Антен ${ }^{5}$, целом районе дворцов в девятом квартале» [14, p. 345]. Гимар не преминула

5 Шоссе д’Антен - улица в девятом округе Парижа. Здесь находился особняк Луи Антуана де Пардайана де Гондрена, герцога д’Антена (1665-1736), по имени которого улица и была названа. 
сделать мастеру заказ, тем более, что их доброму знакомству уже было положено начало вышеописанным портретом. На стене парадного салона должна была быть изображена сама Гимар в образе музы танца Терпсихоры. Когда работа уже близилась к завершению, между художником и заказчицей произошла бурная ссора, причины которой нам неизвестны. Тем не менее она привела к тому, что Фрагонар был уволен. Мастер, обладавший находчивостью южанина и не слишком покладистым характером, «ловко отомстил за себя, создав шарж, в котором проявились весь его ум и вся злость. Однажды художник незаметно проник в салон. Используя палитру и кисть своего отсутствующего преемника, Фрагонар очень быстро переписал улыбку Терпсихоры, переменив ее на гримасу ярости и придав богине черты Тисифоны ${ }^{6}$, которая оказалась очень похожа на мадемуазель Гимар. А когда заказчица явилась с друзьями, чтобы продемонстрировать им декорацию своего салона, то пришла в бешенство, обнаружив месть художника» $[14$, p. 346]. Заметим, что преемником Фрагонара в этой работе стал Жан-Луи Давид (1748-1825), у которого впоследствии будет учиться сын Фрагонара и который немало сделает для стареющего мастера в годы Великой французской революции.

Особняк Гимар называли в Париже «Храмом Терпсихоры». На фасаде этого дворца располагалась скульптурная группа, изображавшая Аполлона, коронующего Терпсихору работы скульптора Феликса Леконта (17371817). За колоннами портика шел длинный скульптурный фриз. Украшавший его барельеф изображал также «Музу танца на колеснице, влекомой амурами, в окружении пляшущих вакханок и фавнов» $[15$, p. 89]. Дворец имел любопытный план в виде сильно вытянутой по горизонтали трапеции, причем фасад находился на скошенной стороне. На втором этаже прямо над входом располагался домашний театр Гимар. Этот дворец на Шоссе д’Антен был разрушен при перестройке Парижа по плану Османа. О композициях работы Фрагонара известно только, что их было четыре, две $260 \times 309$ см и две $245 \times 300$ см. Продан-

\footnotetext{
${ }^{6}$ Тисифона - одна из эриний, богинь мести.
}

ные в 1844 г. и с того времени навсегда исчезнувшие, эти произведения представляли собой «Идеальные мифологические сцены, украшенные всем, на что воображение мастера было способно» [6, p. 365]. К. Моклер утверждает, что произведения были «очень светлыми по колориту» [16, p. 37], однако не уточняет источник этой информации.

Известно, что в Париже середины - второй половины XVIII в. проходило большое количество разнообразных ярмарок. В течение года они сменяли друг друга. Одной из самых любимых была ярмарка Св. Лорана, длившаяся с 9 августа по 29 сентября. Посетители могли провести время в уличных кафе, сделать покупки в бесчисленных лавках, поиграть в бильярд и шары, а также насладиться представлениями, которые давала как Опера-Комик, так и менее значительные, но великие числом бульварные театрики, в том числе марионеточные. С 3 февраля и до Страстной пятницы (на какой бы день она ни пришлась) проходила ярмарка Сен-Жермен. Она считалась наиболее значительной и также предполагала большое количество спектаклей. Были и другие ярмарки, такие как ярмарка Св. Лазаря и Св. Овидия, знаменитая своими ночными иллюминациями, от чего увеселения, в том числе и спектакли, могли продолжаться здесь далеко за полночь.

Труппы, развлекающие публику своими представлениями, выступали в различных жанрах. Наиболее распространена была комедия, как французская, так и итальянская. После закрытия Театра итальянской комедии в 1697 г. ${ }^{7}$ во Франции организовывались маленькие театрики, где действовали все те же герои комедии дель арте, адаптировавшиеся, впрочем, к окружающей среде. Как пишет М. Герман, «от спектакля к спектаклю он делался все менее итальянским - он становился французским итальянским театром. Маски и амплуа смешивались, как смешивался язык: все чаще актеры играли пусть с акцентом, но по-французски $<. .>$ все больше шло французских - и первоклассных - пьес <...>. Опера согласилась, наконец, дать право петь ярмарочным комедиан-

7 Людовик XIV изгнал итальянскую труппу из Парижа за сатиру на госпожу де Ментенон. 


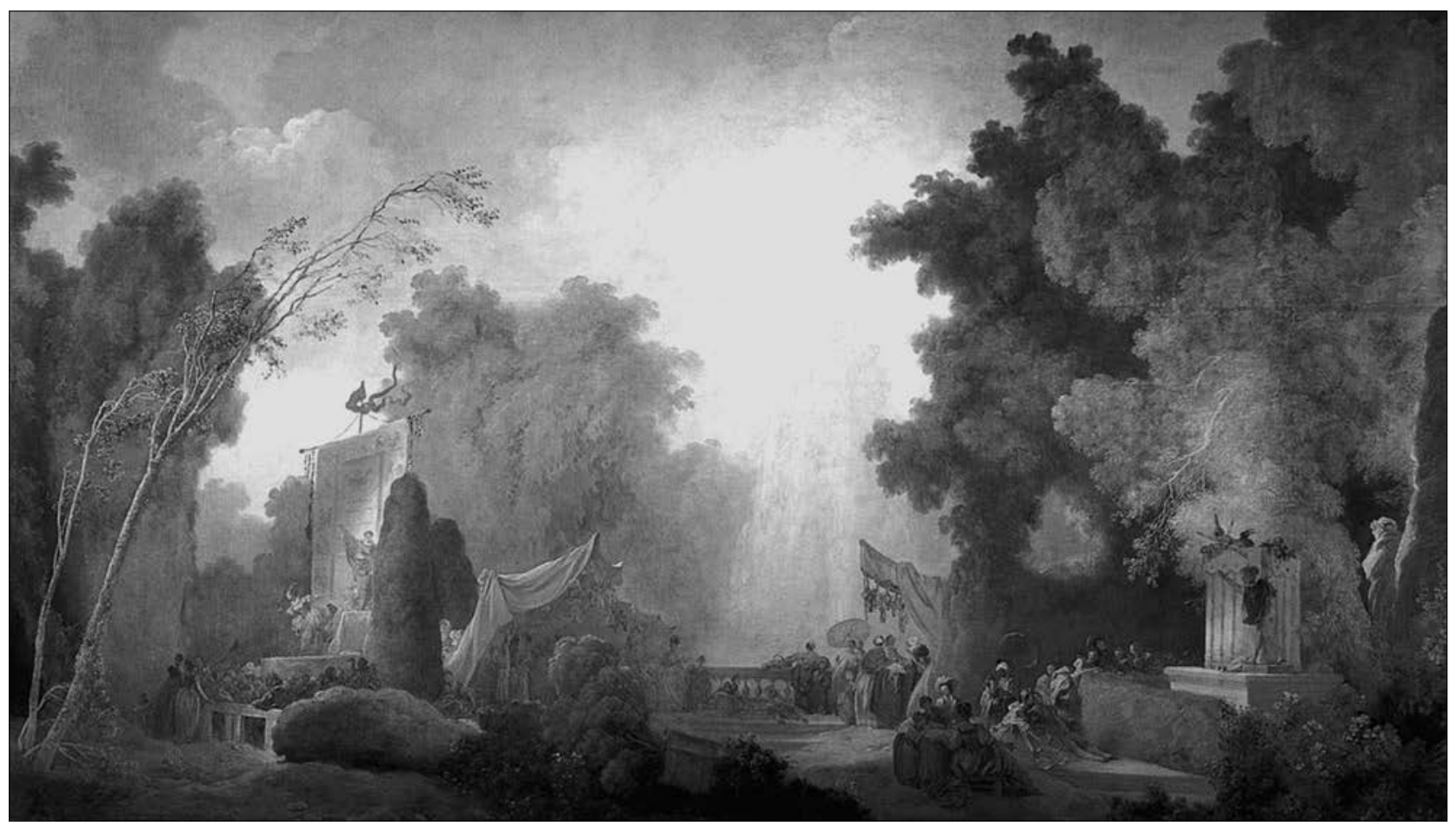

Рис. 3. Ж.-О. Фрагонар. Праздник в Сен-Клу.

1770-1772. Масло, холст. 216 × 335. Отель де Тулуз, Париж

там, которые пользовались, как был уже случай упомянуть, до той поры лишь условными символическими мелодиями» [17, с. 109]. Чрезвычайно распространены оказались и цирковые представления. Публика могла подивиться ловкости акробатов и канатоходцев, пообщаться с «живой головой», помериться ростом с карликами и великанами.

К 1770-м гг. Фрагонар создает несколько жанровых полотен, которые нам хочется назвать «панорамными», поскольку на них в масштабном природном окружении происходит действо с большим количеством персонажей, которых можно было бы назвать стаффажем, если бы не сугубый интерес, который представляют для зрителя их занятия. Интересующее нас полотно (рис. 3) носит название «Праздник в Сен-Клу» (1770-1772, Отель де Тулуз, Париж). Название относится к 1885 г. и не является оригинальным, хотя и отражает реалии парижской жизни XVIII века. В самом деле, в сентябре в садах Сен-Клу традиционно проходили народные гуляния.

Картина имеет вытянутый горизонтальный формат. С левой стороны изображена высокая сцена, на которой происходит какое-то захватывающее действие. Изящная актриса в пышном платье картинно наклоняется к собравшейся внизу публике. Справа расположились торговцы, вокруг которых толпятся женщины с детьми. В нижнем правом углу юноши и девушки смотрят кукольное представление, что-то вроде марионеточной комедии дель арте. Исполненные изящества сценки происходят в поистине величественном окружении. Деревья, повторяющие форму облаков, возносят в небеса свои мощные кроны. Справа, отделенный парапетом от террасы с гуляющей публикой, бурлит фонтан. Гигантский столб воды, десятикратно превосходящий человеческий рост, взмывает вверх, больше напоминая величественный горный водопад, чем творение рук человеческих. Для всей этой панорамы Фрагонар выбирает приглушенный пастельный колорит, варьируя зеленые, бежевые, розовые и голубые оттенки. Сцена кажется слегка подернутой дымкой, словно воспоминание, на миг явившееся перед глазами зрителей. Дух парижской ярмарки не становится менее выраженным оттого, что Фрагонар, прекрасный пейзажист и боль- 
шой ценитель садов и парков, поместил сценки в природное окружение.

Дальнейшее изучение творчества Фрагонара может выявить и другие случаи соприкосновения мастера с театральной культурой своего времени. Однако и приведенных примеров достаточно, чтобы ощутить, насколько сильным было влияние сцены даже на художника, который никогда не работал в качестве театрального декоратора и оказывался в театре не иначе, как зрителем. Театр пропитывал художественную среду Парижа XVIII века. Он проникал в мастерские живописцев, в интеллектуальные салоны и будуары дам, заставляя как художников, так и заказчиков мыслить в театральных категориях. Большие исторические полотна превращались в тонко срежиссированные сцены, где герои действовали в окружении архитектуры, повторяющей театральные декорации, а модели портретов выбирали для себя самые причудливые роли, в которых «выступали» на полотнах ${ }^{8}$. Ярмарочный театр, наиболее демократичный, представлял живые и запоминающиеся образы, привлекающие мастеров кисти своей непосредственностью. Фрагонар сумел отразить в своем творчестве различные аспекты театральной культуры, и произведения его могут служить показателем того, насколько восприимчиво оказалось искусство рококо ко всему, что связано со сценой.

\section{Список источников}

1. Leroy A. Quentin de La Tour et la société française du XVIIIe siècle. Paris : Edition Albin Michel, 1953. $350 \mathrm{p}$.

2. Kahn G. Fragonard // L’art et le Beau. № 3, 1907. $36 \mathrm{p}$.

3. Fenaille M. François Boucher. Paris : Nilsson, 1925. $140 \mathrm{p}$.

4. Бенуа А. Фердинандо Биббиена Галли // Художественные сокровища России. 1901, № 3. C. $40-56$.

5. Courajod L. Histoire de l'Ecole des Beaux-Arts au XVIIIe siècle. L'école royale des élèves protégés.
Paris : J. Rouam, éditeur ; London : Gilbert Wood \& Co, 1850. $264 \mathrm{p}$.

6. Rosenberg P. Fragonard. Paris : Edition de la Réunion des musées nationaux, 1987. 638 p.

7. Nolhac P. de. Fragonard. Paris : Goupil \& Cie Manzi, Joyant \& Cie, 1918. 224 p.

8. Théâtre de Cour : Les spectacles à Fontainebleau au XVIIIe siècle. Paris : Edition de la Réunion des musée nationaux, 2005. $199 \mathrm{p}$.

9. Дидро Д. Салоны. Т. 1. Москва : Искусство, 1989. 270 c.

10. Explication des peintures, sculptures, et gravures de messieurs de l'Académie royale Dont l'exposition a été ordonnée suivant l'intention de Sa Majesté, par M. Le Marquis de Marigny, Conseiller du Roi en ses Conseils, Commandeur de ses ordres, Lieutenant Général des Provinces de Beauce \& d'Orléanois, Directeur Géneral des Batimens de sa Majesté, Jardins, Arts, Académie \& Manufactures Royales. Paris : De l'Imprimerie de Jean-Th. Herissant, 1765. $48 \mathrm{p}$.

11. Mathon de La Cour Ch.-J. Troisième lettres à Monsieur ** , sur les Peintures, les Sculptures \& Gravures, exposées au Sallon du Louvre en 1765. Paris, $1765.99 \mathrm{p}$.

12. Callirhoé, tragédie, représentée pour la première fois par l'Académie royale de musique le mardi vingt-septième décembre 1712. Paris : C. Ballard, $1712.63 \mathrm{p}$.

13. Cuzin J.-P. Fragonard. Leben und Werk. München : Klinghardt u. Biermann, 1988. 386 S.

14. Goncourt Ed. et J. L'art du dix-huitième siècle. Gravelot. Cochin. Eisen. Moreau. Debucourt. Fragonard. Prudhon. Vol. 2. Paris : Rapilly, 1874. $555 \mathrm{p}$.

15. Goncourt Ed. La Guimard d'après les registres des menus-plaisirs de la Bibloithèque de l'Opéra ect. Paris : G. Charpentier \& E. Fasquelle, 1893.331 p.

16. Mauclair C. Fragonard. Biographie critique. Paris : Henri Laurens, 1904. 128 p.

17. Герман М. Антуан Ватто. Ленинград : Искусство, 1984. $208 \mathrm{c}$.

18. Frantz $P$. L'estétique du tableau dans le théâtre du XVIIIe siècle. Paris : PUF, 1998. 296 p.

\footnotetext{
${ }^{8}$ Существовала и обратная связь. Самым известным примером может считаться картина Ж.-Б. Греза «Деревенская помолвка», практически точно воспроизведенная на сцене в конце последнего акта спектакля «Свадьба Арлекина», поставленного Итальянским театром в 1761 году. См.: [18, p. 178].
} 


\section{Jean-Honoré Fragonard's Work and the Theatre Culture of the 18th Century}

\section{Elena E. Agratina}

Moscow State Academy of Choreography, 5, 2nd Frunzenskaya Str., Moscow, 119146, Russia ORCID 0000-0001-9842-0967; SPIN 6691-3631 E-mail: agratina_elena@mail.ru

\begin{abstract}
The article, for the first time, examines the work of the master of the 18th century Jean-Honoré Fragonard (1732-1806) within the context of the theatre culture of that time. Being a student of François Boucher (1703-1770), who was working as a theater decorator for a long time, Fragonard from his youth had the opportunity to join the world of theater. The painter's passion for the stage greatly influenced the thematic and figurative composition of his works. Early historical paintings of Fragonard, such as "Jeroboam Sacrifcing to Idols" (1752, School of Fine Arts, Paris), were created under the influence of Baroque theater and decorative art and opera productions. Undoubtedly, Fragonard's familiarity with theatre was promoted by his long stay in Italy, where the famous families of theater decorators Bibiena and Galliari was working at that time. The article pays special attention to the process of planning and execution of the painting "The High Priest Coresus Sacrificing Himself to Save Callirhoe" (1765, Louvre), made not without regard to the opera "Callirhoe", popular in Paris in the 18th century. It was theater that inspired the master to create his famous costume series of "Fantasy Portraits", one of which depicted Marie-Madeleine Guimard (1743-1816), who not only had posed for the artist, but also ordered him to design her own mansion conceived as a temple of Terpsichore, the Muse of dance. In addition, Fragonard was the author of several panoramic genre paintings conveying the atmosphere of the then popular street theater. Works of this brilliant master exemplify the relationship of arts that determined the nature of the cultural environment of that era and requires constant attention from modern researchers.
\end{abstract}

Key words: 18th century art, Rococo, painting, theatre, theatrical art.
Citation: Agratina E.E. Jean-Honoré Fragonard's Work and the Theatre Culture of the 18th Century, Observatory of Culture, 2019, vol. 16, no. 4, pp. 406-417. DOI: $10.25281 / 2072-3156-2019$ 16-4-406-417.

\section{References}

1. Leroy A. Quentin de La Tour et la société française du XVIIIe siècle. Paris, Edition Albin Michel, 1953, $350 \mathrm{p}$.

2. Kahn G. Fragonard, L'art et le Beau, no. 3, 1907, $36 \mathrm{p}$.

3. Fenaille M. François Boucher. Paris, Nilsson Publ., 1925, $140 \mathrm{p}$.

4. Benois A. Ferdinando Bibbiena Galli, Khudozhestvennye sokrovishcha Rossii [Art Treasures of Russia], 1901, no. 3, pp. 40-56 (in Russ.).

5. Courajod L. Histoire de l'Ecole des Beaux-Arts au XVIIIe siècle. L'école royale des élèves protégés. Paris, J. Rouam Publ., London, Gilbert Wood \& Co Publ., 1850, $264 \mathrm{p}$.

6. Rosenberg P. Fragonard. Paris, Edition de la Réunion des Musées Nationaux, 1987, $638 \mathrm{p}$.

7. Nolhac P. de. Fragonard. Paris, Goupil \& Cie Manzi, Joyant \& Cie Publ., 1918, 224 p.

8. Théâtre de Cour: Les spectacles à Fontainebleau au XVIIIe siècle. Paris, Edition de la Réunion des Musée Nationaux, 2005, 199 p.

9. Diderot D. Salony [Salons], vol. 1. Moscow, Iskusstvo Publ., 1989, 270 p.

10. Explication des peintures, sculptures, et gravures de messieurs de l'Académie royale Dont l'exposition a été ordonnée suivant l'intention de Sa Majesté, par M. Le Marquis de Marigny, Conseiller du Roi en ses Conseils, Commandeur de ses ordres, Lieutenant Général des Provinces de Beauce E d'Orléanois, Directeur Géneral des Batimens de sa Majesté, Jardins, Arts, Académie \& Manufactures Royales. Paris, De l'Imprimerie de Jean-Th. Herissant Publ., 1765, 48 p.

11. Mathon de La Cour Ch.-J. Troisième lettres à Monsieur ** sur les Peintures, les Sculptures \& Gravures, exposées au Sallon du Louvre en 1765. Paris, 1765, $99 \mathrm{p}$.

12. Callirhoé, tragédie, représentée pour la première fois par l'Académie royale de musique le mardi vingt-septième décembre 1712. Paris, C. Ballard Publ., 1712, 63 p.

13. Cuzin J.-P. Fragonard. Leben und Werk. Munich, Klinkhardt u. Biermann Publ., 1988, 386 p. 
14. Goncourt Ed. et J. L'art du dix-huitième siècle. Gravelot. Cochin. Eisen. Moreau. Debucourt. Fragonard. Prudhon, vol. 2. Paris, Rapilly Publ., 1874, 555 p.

15. Goncourt Ed. La Guimard d'après les registres des menus-plaisirs de la Bibloithèque de l'Opéra ect. Paris, G. Charpentier \& E. Fasquelle Publ., 1893, 331 p.
16. Mauclair C. Fragonard. Biographie critique. Paris, Henri Laurens Publ., 1904, 128 p.

17. German M. Antoine Watteau. Leningrad, Iskusstvo Publ., 1984, 208 p. (in Russ.).

18. Frantz P. L'estétique du tableau dans le théâtre du XVIIIe siècle. Paris, PUF Publ., 1998, 296 p.

Всероссийская научно-практическая конференция

\title{
«ИНФОРМАЦИОННЫЙ КОНТЕКСТ КУЛЬТУРЫ: РЕСУРСЫ, ТЕХНОЛОГИИ, СЕРВИС»
}

\author{
24-25 сентября 2019 г., \\ Российская государственная библиотека, Москва
}

Российская государственная библиотека, Российская государственная библиотека искусств и Санкт-Петербургский государственный институт культуры приглашают вас принять участие во Всероссийской научно-практической конференции «Информационный контекст культуры: ресурсы, технологии, сервис».

Цель конфреренции - обобщение научных исследований и практического опыта по вопросам информационного обеспечения сфреры культуры и искусства в цифровую эпоху, демонстрация лучших достижений, выявление проблем и путей их преодоления.

Основные тематические направления конференции:

- инорормационные ресурсы по культуре и искусству: виды, темы, фрормы, технологии ведения, условия доступа, оценка качества и стратегии развития;

- современная практика продвижения информационных ресурсов, продуктов и услуг в цифровой среде;

- Год театра в России: информационные ресурсы, посвященные театральному искусству;

- роль и возможности библиотек в информационном обеспечении реализации национального проекта «Культура»;

- сотрудничество библиотек, музеев, архивов и сетевых медиа в области формирования и развития доступа к информационным ресурсам по культуре и искусству;

- основные тенденции и проблемы цифровизации информационной деятельности в ссрере культуры;

- современные технологии и формы библиотечно-информационного обслуживания руководителей и специалистов сферы культуры, представителей творческих профессий.

В рамках конференции состоится XI конференция (совещание) руководителей и специалистов служб информации по культуре и искусству и заседание Совета Росинформкультуры.

\section{Контакты:}

Васильева Ирина Владимировна, заместитель заведующего Центром по исследованию проблем развития библиотек в информационном обществе тел.: +7 (495) 695-78-63, e-mail: VasilevalV@rsl.ru

Регистрация и подробная информация: https://www.rsl.ru/ru/events/afisha/conf/info-kontekst-kultury 